\title{
Refrigeration of donor cells in preparation for bovine somatic nuclear transfer
}

\author{
J-L. Liu' ${ }^{1}$, M-K. Wang1, Q-Y. Sun ${ }^{1}$, X-R. Zhang², L-K. Jiang ${ }^{3}$ \\ and D-Y. Chen ${ }^{1 *}$ \\ ${ }^{1}$ State Key Laboratory of Reproductive Biology, Institute of Zoology, Chinese Academy of \\ Sciences, Beijing, China; ${ }^{2}$ Department of Animal Science, Anhui Agricultural University, \\ Hefei, China; and ${ }^{3}$ Department of Biotechnology, Anhui Agricultural University, Hefei, China
}

In mammals, preparation of donor cells for somatic nuclear transfer is very important because the character of the donor cell directly affects the efficiency and outcome of transfer. The protocols used most commonly for donor preparation are (i) disaggregating cells from fresh tissue 1-2 $\mathrm{h}$ before micromanipulation or (ii) trypsinizing cultured cells temporarily, after special treatments for 3-8 days (for example, serum starvation). In this study, a new simple protocol was designed, whereby the donor cells (cumulus cells) used in bovine somatic nuclear transfer were refrigerated. In brief, cultured cells at $\mathbf{8 0 - 1 0 0 \%}$ confluency were detached using trypsin, washed by centrifugation, aliquoted into different vials and refrigerated at $4^{\circ} \mathrm{C}$. The density of viable cells was decreased after day 1 of refrigeration; however, the rate of decrease tended to slow down with increasing duration of refrigeration. Cells refrigerated for 15 days were seeded at a density of $5 \times 10^{4} \mathrm{ml}^{-1}$ and reached $70 \%$ confluency after day 2 of culture. Most cells had the normal number of chromosomes $(2 n=60)$. Cells chilled at $4^{\circ} \mathrm{C}$ for different durations were removed from refrigeration and immediately subjected to micromanipulation. The in vitro development of reconstructed embryos (fusion rates, cleavage rates, morula and blastocyst rates) indicated that there were no significant differences among treatment groups regardless of the duration of refrigeration $(0-2$ weeks) of the donor cells. Reconstructed embryos were transferred into the uteri of recipient cows. No significant differences were observed in established early pregnancies between embryos derived from the non-refrigerated donor cells and those derived from refrigerated donor cells. This study indicates that refrigeration of donor cells for 1-2 weeks is a feasible protocol for preparing donor cells for bovine somatic nuclear transfer, and does not compromise development in vitro and early development in vivo.

\section{Introduction}

Nuclear transfer using cultured cell lines avoids some of the limiting factors of embryonic nuclear transfer, such as the complex steps for preparing donor embryos and the limited quantity of donor blastomeres (Campbell et al., 1996; DiBerardino, 1997). A similar protocol led to the cloning of animals derived from fetal or adult cells (Wilmut et al., 1997). The benefits of somatic nuclear transfer include: (i) somatic cell culture is simple compared with the complex steps required for preparing donor embryos; (ii) as the stage of the cell cycle is important in the coordination of the donor nuclei and recipient ooplasm, the cell cycle of cultured somatic cells is easier to control than that of embryo blastomeres; (iii) old or endangered animals can provide somatic cells as donors in somatic nuclear transfer, whereas it is difficult or impossible to

*Correspondence

Email: chendy@panda.ioz.ac.cn obtain oocytes or embryos from those animals for embryonic nuclear transfer; (iv) large-scale genetically identical animals can be obtained through somatic nuclear transfer, but not through embryonic nuclear transfer; and (v) somatic nuclear transfer offers an alternative means of cellmediated transgenesis in farm animals (Wilmut, 1998; Wolf et al., 1998; Kubota et al., 2000; McCreath et al., 2000; Denning et al., 2001). Somatic nuclear transfer broadens the future of cloning techniques and during the past 4 years has led animal cloning into a 'golden era' (Wilmut et al., 1997; Kato et al., 1998; Wakayama et al., 1998a; Baguisi et al., 1999; Onishi et al., 2000).

Donor cell preparation is an important but easily overlooked step in nuclear transfer. In each batch, the number of donor cells generally exceeds the number of recipient oocytes available. Somatic cells were refrigerated for 1 or 2 weeks to study the effect of refrigeration on donor cells and on nuclear transfer as assessed by the fusion rate, development in vitro and early development in vivo. The aim of the present study was to simplify the procedure for donor cell preparation. 


\section{Materials and Methods}

\section{Animals and chemicals}

Donor cells and oocytes were obtained from a local abattoir. Recipient cows came from the Anhui SinoGermany Friendship Farm.

Dulbecco's modified Eagle's medium/nutrient mixture F-12 (DMEM/F12, containing Hepes) was purchased from HyClone (Logan, UT), 0.25\% (w/v) trypsin and M-199 (medium 199 with Earle's salts) were purchased from GIBCO (Grand Island, NY), fetal bovine serum (FBS) was purchased from Chuanye Biochemical Co. (Tianjin), and pig $\mathrm{FSH}$ and $\mathrm{LH}$ were obtained from the Institute of Zoology, Chinese Academy of Sciences (Beijing). All other biochemicals were purchased from Sigma (St Louis, MO), unless noted otherwise.

\section{Cumulus cell culture}

Ovaries from adult cows were obtained from a local abattoir and transported to the laboratory in saline at $4^{\circ} \mathrm{C}$. Ovaries were washed in saline, immersed in $75 \%(\mathrm{v} / \mathrm{v})$ ethanol for $30 \mathrm{~s}$ and then washed again, four to five times, in saline. Oocytes were aspirated from 2-8 $\mathrm{mm}$ follicles. Cumulus-oocyte complexes (COCs) from individuals that had multiple layers of cumulus cells were collected and vortexed in $0.1 \%(\mathrm{w} / \mathrm{v})$ hyaluronidase in PBS. After the oocytes were removed, cumulus cells were washed by centrifugation at $750 \mathrm{~g}$ for $10 \mathrm{~min}$ and then seeded in DMEM/F12 plus $20 \%$ FBS in $25 \mathrm{ml}$ cell culture flasks at a density of $5 \times 10^{4} \mathrm{ml}^{-1}$ in a humidified atmosphere of $5 \%$ $\mathrm{CO}_{2}$ in air at $38.5^{\circ} \mathrm{C}$ (Liu et al., 2000).

\section{Preparation of donor cells}

Cultured cumulus cells (2-4 passages) at $80-100 \%$ confluency were used as donor cells in nuclear transfer. The chromosomes of some cells were analysed after reaching 80-100\% confluency. Other cells from the same batch were detached at $80-100 \%$ confluency using $0.25 \%$ trypsin at $37^{\circ} \mathrm{C}$ for $2 \mathrm{~min}$. After washing three times by centrifugation at $750 \mathrm{~g}$ each for $10 \mathrm{~min}$, the cells were added to serum-free DMEM/F12 (containing Hepes) and aliquoted into $1.5 \mathrm{ml}$ sterilized tubes at a density of $2 \times 10^{5} \mathrm{ml}^{-1}$, and stored at $4^{\circ} \mathrm{C}$. Some tubes were maintained at $37^{\circ} \mathrm{C}$ and served as controls.

\section{Oocyte recovery and in vitro maturation}

Bovine ovaries were maintained in physiological saline at $30-35^{\circ} \mathrm{C}$ and transported to the laboratory within $3 \mathrm{~h}$ after the animal had been killed. COCs were collected by aspirating 2-8 $\mathrm{mm}$ antral follicles with an 18-gauge needle and a $10 \mathrm{ml}$ syringe. After washing three times in Dulbecco's PBS supplemented with $0.1 \%(\mathrm{w} / \mathrm{v})$ polyvinyl alcohol (DPBS + PVA), COCs with intact or at least four layers of cumulus cells and dark, evenly granulated cytoplasm were selected for maturation. The maturation medium was M199 and 10\% FBS supplemented with $0.5 \mu \mathrm{g}$ pig FSH ml ${ }^{-1}, 5.0 \mu \mathrm{g}$ pig $\mathrm{LH} \mathrm{m}^{-1}$ and $1.0 \mu \mathrm{g}$ oestradiol $\mathrm{ml}^{-1}$ (Liu et al., 2000). COCs were cultured in $50 \mu$ droplets of maturation medium (10-15 oocytes per droplet) in an atmosphere of $5 \% \mathrm{CO}_{2}$ in humidified air at $38.5^{\circ} \mathrm{C}$.

\section{Nuclear transfer}

Oocytes matured for 20-22 h were separated from the cumulus cells by exposure to $0.1 \%(\mathrm{w} / \mathrm{v})$ hyaluronidase followed by vortexing. Oocytes emitting the first polar body were washed three times in Dulbecco's PBS containing $7.5 \mu \mathrm{g}$ cytochalasin $\mathrm{B} \mathrm{ml}^{-1}$ and then placed in the same medium under mineral oil for $15 \mathrm{~min}$. The first polar body and $30 \%$ of the cytoplasm beneath it were removed with a $35 \mu \mathrm{m}$ (outer diameter) glass pipette. Successful enucleation was confirmed by Hoechst 33342 staining. Donor cells were transferred to the perivitelline space of the recipient oocytes. A previous study indicated that a large portion of cultured cells were at the G0/G1 stage in a population of small cells (Boquest et al., 1999). Therefore, only small cells (with a diameter of approximately 20-25 $\mu \mathrm{m}$ ) were used in the present study to increase the possibility of obtaining donor cells at the G0/G1. After transfer, cell-oocyte complexes were placed into Zimmerman's cell fusion medium (containing $\mathrm{Ca}^{2+}$ ) in a $1 \mathrm{~mm}$ fusion chamber and a pulse of $1.2 \mathrm{kV} \mathrm{cm}^{-1}$ for $20 \mu \mathrm{s}$ was applied to induce the cells to fuse (Wolfe and Kraemer, 1992). After $1 \mathrm{~min}$, the cell-oocyte pairs were transferred to $\mathrm{M} 199+10 \%$ FBS and placed in a $5 \% \mathrm{CO}_{2}$ incubator at $38.5^{\circ} \mathrm{C}$. After approximately 20-30 min, the cell-oocyte pairs were examined for fusion under an inverted phasecontrast microscope and a second pulse was applied to cell-oocyte pairs that had not fused.

\section{Activation and in vitro culture}

One hour after the second pulse, fused cell-cytoplast complexes were activated by exposure to $5 \mu \mathrm{mol}$ calcium ionophore $\mathrm{A} 2318 \mathrm{I}^{-1}$ at room temperature for $5 \mathrm{~min}$ followed by incubation with $10 \mu \mathrm{g}$ cycloheximide $\mathrm{ml}^{-1}$ plus $5 \mu \mathrm{g}$ cytochalasin $\mathrm{B} \mathrm{ml}^{-1}$ for $5 \mathrm{~h}$. The reconstructed oocytes were washed and then cultured in CR1aa containing $3 \mathrm{mg}$ BSA $\mathrm{ml}^{-1}$ (Rosenkrans and First, 1991) for 2 days in an atmosphere of $5 \% \mathrm{CO}_{2}$ in humidified air at $38.5^{\circ} \mathrm{C}$. The cleavage rates were recorded and cleaved embryos were co-cultured with a granulosa cell monolayer in CR1aa plus $10 \%$ FBS.

\section{Embryo transfer}

Reconstructed embryos were cultured for 6-8 days (day of fusion = day 0). Good quality compacted morulae, early blastocysts, blastocysts or expanded blastocysts were transferred non-surgically into the uterine horn ipsilateral to the corpus luteum of synchronized recipients. Each cow received one or two blastocysts or three or four morulae. After transfer, each recipient was observed three times each day to detect signs of oestrus. 


\section{Experimental design}

Experiment 1: measurement of the densities of refrigerated cells. Three tubes of cells refrigerated at $4{ }^{\circ} \mathrm{C}$ were removed from the refrigerator and agitated by blowing gently through a pipette. After the addition of $0.1 \%(\mathrm{w} / \mathrm{v})$ Trypan blue, the densities of viable cells were measured three times for each tube using a haemocytometer.

Experiment 2: measurement of the percentages of viable cells. Cells stored at $4^{\circ} \mathrm{C}$ or $37^{\circ} \mathrm{C}$ for 15 days and freshly detached cells were aspirated to dishes, stained by $1 \mu \mathrm{g}$ Hoechst $33342 \mathrm{ml}^{-1}$ for $5 \mathrm{~min}$ and observed using inverted microscopy under UV and common light. The percentages of viable cells in each group were measured at least three times by counting the number of cells in the same field of view under UV and common light, as only non-viable cells could be stained and were visible under UV light.

Experiment 3: seeding of refrigerated cells and chromosome analysis. Cells refrigerated at $4{ }^{\circ} \mathrm{C}$ for 15 days were seeded in 24-well cell culture plates and $25 \mathrm{ml}$ flasks, and cultured in DMEM/F12 under a humidified atmosphere of $5 \% \mathrm{CO}_{2}$ in air at $38.5^{\circ} \mathrm{C}$. Cell morphology was observed each day under phase-contrast microscopy. Cells reaching $80 \%$ confluency were subjected to chromosomal analysis using the method described by Freshney (1994). In brief, after the cells had been cultured in fresh-changed culture medium containing $0.3 \mu \mathrm{g}$ colchicine $\mathrm{ml}^{-1}$ for $4 \mathrm{~h}$, they were detached using $0.25 \%$ trypsin and agitated by blowing through a pipette. The cell suspension was placed into $10 \mathrm{ml}$ tubes and centrifuged at $750 \mathrm{~g}$ for $10 \mathrm{~min}$. Subsequently, the cells were incubated in $6 \mathrm{ml}$ hypotonic $\mathrm{KCl}\left(75 \mathrm{mmol} \mathrm{I}^{-1}\right)$ solution at $37^{\circ} \mathrm{C}$ for $20 \mathrm{~min}$ and then prefixed by the addition of $2 \mathrm{ml}$ fresh fixative (methanol:acetic acid = 3:1). After centrifugation (750 g, $10 \mathrm{~min})$, cells were fixed in the same fixative three more times. After the last centrifugation, $0.5-1.0 \mathrm{ml}$ of the cell suspension containing fixative was dropped on to frozen clean microscope slides. After drying, the slides were stained with 5\% (w/v) Giemsa for $10 \mathrm{~min}$. The numbers of well spread chromosomes within a clear cell boundary were counted under a light microscope.

Experiment 4: nuclear transfer using freshly detached or refrigerated donor cells. Freshly detached cells or cells that had been refrigerated for different periods of time (1 or 2 weeks) were used as donors in nuclear transfer with the same protocol as described above. The donor cells (at passage 2-4) in each group originated from the same primary culture. Fusion rates, as well as cleavage, morula and blastocyst rates were recorded and used as criteria to evaluate the effect of refrigeration on donor cells and on nuclear transfer. Each group had at least three replicates. The development in vivo of reconstructed embryos that were transferred into the uteri of recipients was evaluated by observing recipients for signs of oestrus as described above.
Statistical analysis

All data were analysed by the chi-squared test.

\section{Results}

\section{Experiment 1: densities of refrigerated cells}

Detached cells at a density of $2 \times 10^{5} \mathrm{ml}^{-1}$ were refrigerated at $4^{\circ} \mathrm{C}$. After day 1 of refrigeration, the average density of viable cells decreased by $28 \%$ to $1.44 \times 10^{5} \mathrm{ml}^{-1}$; however, the rate of decrease tended to slow down with increasing duration of refrigeration. The density of viable cells refrigerated for 15 days decreased to $9.7 \times 10^{4} \mathrm{ml}^{-1}$, which is half the density before refrigeration (Fig. 1).

\section{Experiment 2: percentages of viable cells}

Of freshly detached cells, $95.1 \pm 2.3 \%$ were viable. After the cells had been stored for 15 days, $72.9 \pm 5.7 \%$ of cells maintained at $4^{\circ} \mathrm{C}$ were viable, whereas $99.3 \pm 0.2 \%$ of cells maintained at $37^{\circ} \mathrm{C}$ were not viable (Fig. 2)

\section{Experiment 3: morphology of seeded refrigerated cells and chromosome analysis}

When cells at passage 2 reached $80 \%$ confluency, they were subjected to chromosome analysis. Of 114 cells analysed, 93 cells $(82 \%)$ had the normal number of chromosomes $(2 n=60)$, whereas there were fewer chromosomes in 13 cells $(11 \%)$ and more chromosomes in eight cells $(7 \%)$ (Table 1$)$.

Cells from another flask of the same batch as analysed above were detached at $80 \%$ confluency and refrigerated at $4^{\circ} \mathrm{C}$. After cooling for 15 days, the cells were seeded in a 24-well plate and $25 \mathrm{ml}$ cell culture flasks at a density of $5 \times 10^{4} \mathrm{ml}^{-1}$ (passage 3 ). At day 1 , cells have the ability to attach to the bottom of the flask (day of seeding = day 0 ); at day 2 they reach $70 \%$ confluency and at day 3, 100\% confluency (Fig. 3).

After 15 days of cooling, cells cultured in a flask to $80 \%$ confluency were subjected to chromosomal analysis. The results showed that 89 of 105 cells $(85 \%)$ were diploid, 14 of 105 cells $(13 \%)$ had a smaller than normal number of chromosomes and 2 of 105 cells $(2 \%)$ had a larger than normal number of chromosomes (Table 1).

There was no significant difference in chromosome analysis between cells before and after refrigeration. This result indicates that refrigeration for 15 days did not cause a reduction in the number of chromosomes.

\section{Experiment 4: development in vitro and in vivo}

Use of freshly detached cells (non-refrigerated) as donors in nuclear transfer resulted in a fusion rate of $68 \%$ (679 of 993). After chemical activation, 58\% (579 of 993) of the reconstructed oocytes (those of good quality) were selected for culture. Of 579 cultured oocyes, 422 (73\%) cleaved and $159(27 \%)$ developed to morula and blastocyst stages (Table 2). 
Table 1. Chromosomal analysis of refrigerated and non-refrigerated bovine cells

\begin{tabular}{|c|c|c|c|c|}
\hline \multirow[b]{2}{*}{ Group } & \multirow[b]{2}{*}{$\begin{array}{c}\text { Number of } \\
\text { spreads counted }\end{array}$} & \multicolumn{3}{|c|}{ Number of cells with } \\
\hline & & $\begin{array}{c}<60 \\
\text { chromosomes } \\
(\%)\end{array}$ & $\begin{array}{c}60 \\
\text { chromosomes } \\
(\%)\end{array}$ & $\begin{array}{c}>60 \\
\text { chromosomes } \\
(\%)\end{array}$ \\
\hline Cells before refrigeration ${ }^{a}$ & 114 & $13(11)$ & $93(82)^{*}$ & $8(7)$ \\
\hline Cells after refrigeration ${ }^{b}$ & 105 & $14(13)$ & $89(85)^{*}$ & $2(2)$ \\
\hline
\end{tabular}

aNormal passaged cells (cells passaged at $80 \%$ confluency). In each batch of cells, some cells were used immediately for chromosomal analysis and others were analysed after refrigeration.

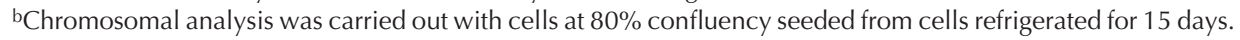

*No significant differences.

Table 2. In vitro development of bovine embryos after nuclear transfer using donor cells refrigerated for different durations

\begin{tabular}{|c|c|c|c|c|c|c|c|}
\hline $\begin{array}{l}\text { Duration of } \\
\text { refrigeration } \\
\text { (weeks) }\end{array}$ & Replicates & $\begin{array}{c}\text { Number of } \\
\text { oocytes } \\
\text { manipulated }\end{array}$ & $\begin{array}{c}\text { Number of } \\
\text { cells fused } \\
(\%)^{\mathrm{a}}\end{array}$ & $\begin{array}{c}\text { Number of } \\
\text { cells cultured } \\
(\%)^{\mathrm{a}}\end{array}$ & $\begin{array}{c}\text { Number of } \\
\text { cells cleaved } \\
(\%)^{b}\end{array}$ & $\begin{array}{c}\text { Number of } \\
\text { morulae } \\
(\%)^{b}\end{array}$ & $\begin{array}{c}\text { Number of } \\
\text { blastocysts } \\
(\%)^{b}\end{array}$ \\
\hline 0 & 19 & 993 & $679(68)$ & $579(58)$ & $422(73)$ & $159(27)$ & $56(10)$ \\
\hline 1 & 8 & 322 & $213(66)$ & 207 (64) & $151(73)$ & $58(28)$ & $23(11)$ \\
\hline 2 & 4 & 151 & $106(70)$ & $104(69)$ & 77 (74) & $31(30)$ & $12(12)$ \\
\hline Total & & 1466 & $998(68)$ & $890(61)$ & $650(73)$ & $248(28)$ & $91(10)$ \\
\hline
\end{tabular}

apercentages were based on total number of manipulated oocytes.

bPercentages were based on the number of cultured reconstructed oocytes.

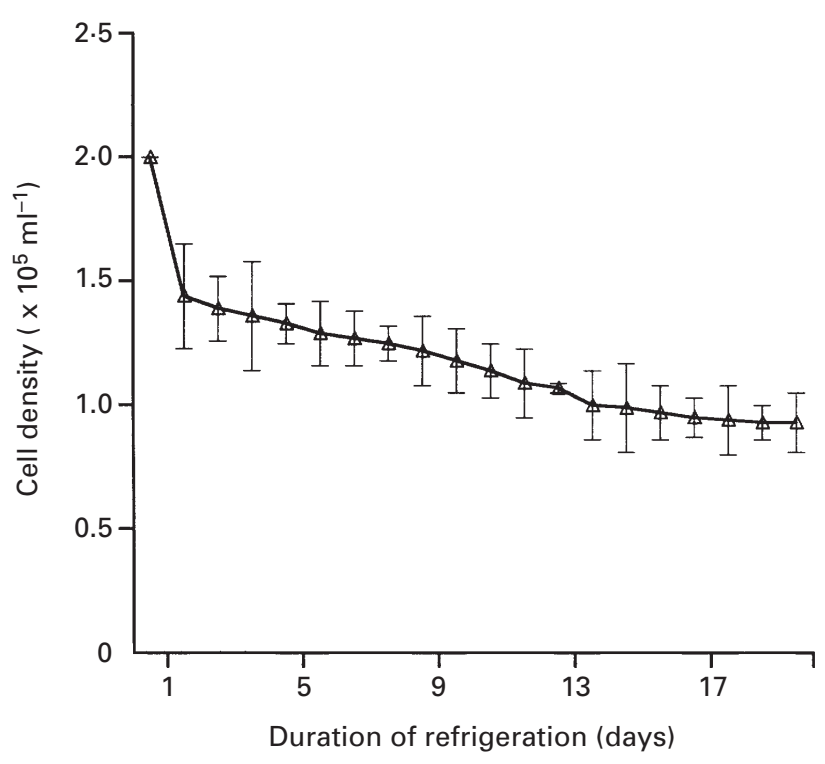

Fig. 1. Cell density of viable bovine cells after refrigeration. Detached cells at a density of $2 \times 10^{5} \mathrm{ml}^{-1}$ were refrigerated at $4^{\circ} \mathrm{C}$ (day 1 ). After day 1 , the average density of viable cells decreased to $1.44 \times 10^{5} \mathrm{ml}^{-1}$. However, the rate of decrease tended to slow down with increasing duration of refrigeration. The density of viable cells refrigerated for 15 days decreased to about half the density before refrigeration.
Cells refrigerated for 1 or 2 weeks, were used as donors in nuclear transfer using the same protocol as for the freshly detached cells. When donor cells were refrigerated for 1 or 2 weeks, the fusion rates and development in vitro were not significantly different from those of the non-refrigerated group (Table 2).

Good quality blastocysts were transferred to the uterus of most recipients. Some recipients received morulae appropriately synchronized relative to the time of oestrus.

Owing to the small number of cells in each group, the data for embryo transfer and in vivo development using cells cooled for 1-2 weeks were pooled.

Thirty-three recipients received a total of 68 embryos reconstructed using freshly detached cells. Twenty-five recipients $(76 \%)$ had not returned to oestrus before day 21 , and $16(48 \%)$ had not returned to oestrus before day 35 .

Nine recipients received a total of 19 embryos reconstructed using cells refrigerated for 1-14 days. Seven recipients $(78 \%)$ had not returned to oestrus before day 21 and four (44\%) pregnancies were ongoing at day 35 . There was no significant difference in early pregnancy rate between the group receiving embryos derived from refrigerated donor cells and that receiving embryos derived from freshly detached donor cells (Table 3). 
Table 3. Results of bovine embryo transfer after reconstruction from refrigerated or non-refrigerated donor cells

\begin{tabular}{lcccc}
\hline $\begin{array}{l}\text { Treatment of } \\
\text { donor cells }\end{array}$ & $\begin{array}{c}\text { Number of } \\
\text { embryos } \\
\text { transferred }\end{array}$ & $\begin{array}{c}\text { Number of } \\
\text { recipients }\end{array}$ & $\begin{array}{c}\text { Pregnancies at } \\
\text { day 21 (\%) }\end{array}$ & $\begin{array}{c}\text { Pregnancies at } \\
\text { day 35 (\%) }\end{array}$ \\
\hline $\begin{array}{l}\text { Non-refrigerated } \\
\text { Refrigerated }\end{array}$ & 68 & 33 & $25(76)$ & $16(48)$ \\
Total & 19 & 9 & $7(78)$ & $4(44)$ \\
\hline
\end{tabular}

aDonor cells were refrigerated for 1 or 2 weeks.

bThe embryos transferred were primarily at the blastocyst stage, although a few embryos at the morula stage were also transferred.
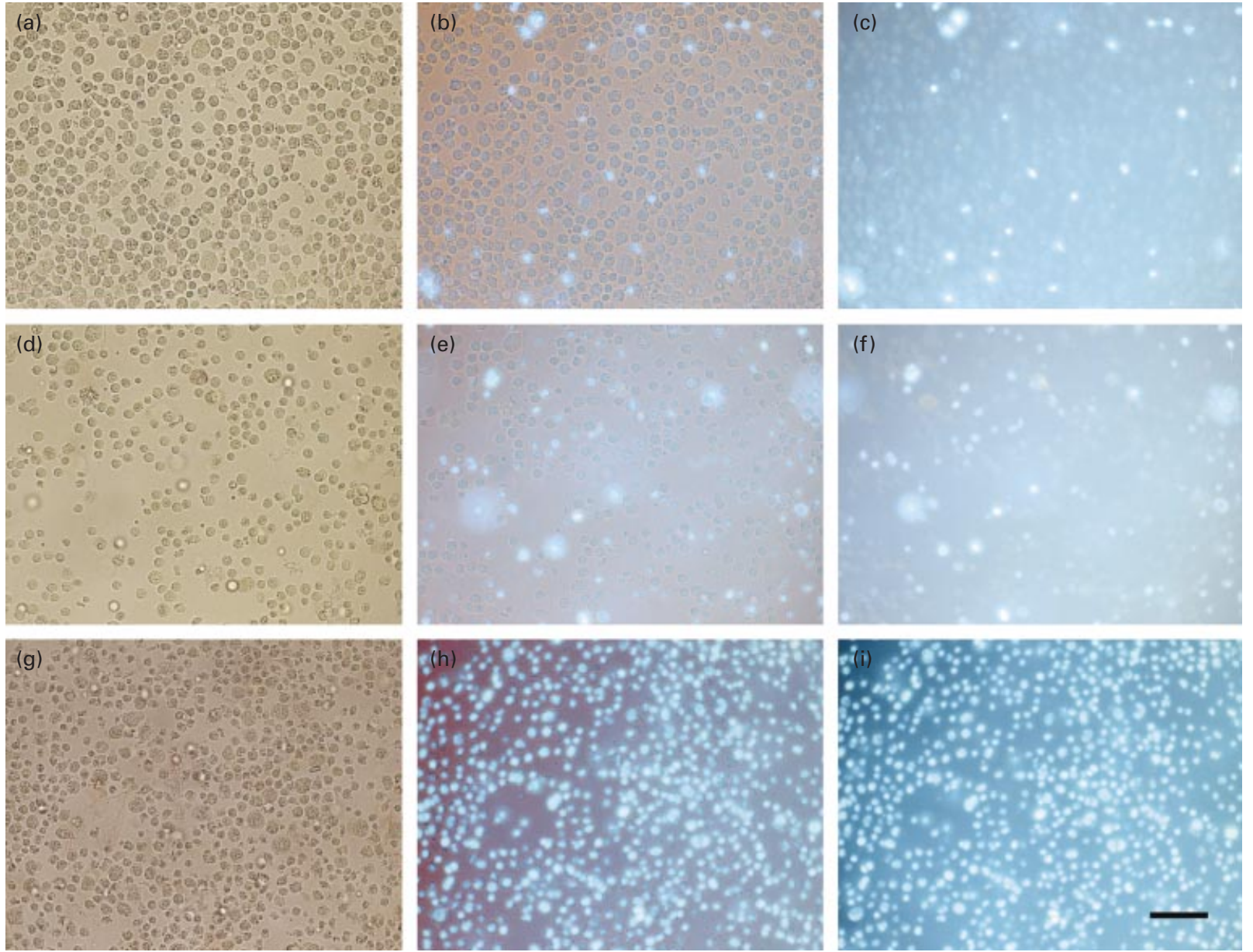

Fig. 2. Bovine cells stained with $1 \mu \mathrm{g}$ Hoechst $33342 \mathrm{ml}^{-1}$ and observed under common light (a,d,g), UV light (c,f,i) or both (b,e,h). Dead cells were stained and visible under UV light, but viable cells were not visible. (a-c) Freshly detached cells (dead cells $<5 \%$ ), (d-f) cells stored at $4^{\circ} \mathrm{C}$ for 15 days (dead cells approximately $30 \%$ ) and (g-i) cells stored at $37^{\circ} \mathrm{C}$ for 15 days (dead cells $>99 \%$ ). Scale bar represents $100 \mu \mathrm{m}$.

\section{Discussion}

In other nuclear transfer studies, three basic protocols have been used to prepare donor cells. In the first protocol, cells are cultured in medium containing a low concentration of serum for several days to induce a quiescence stage (G0) and then detached for nuclear transfer. The serum starvation method was first used in nuclear transfer by a research group at the Roslin Institute in Scotland (Campbell et al., 1996), leading to the birth of the first somatic cloned 

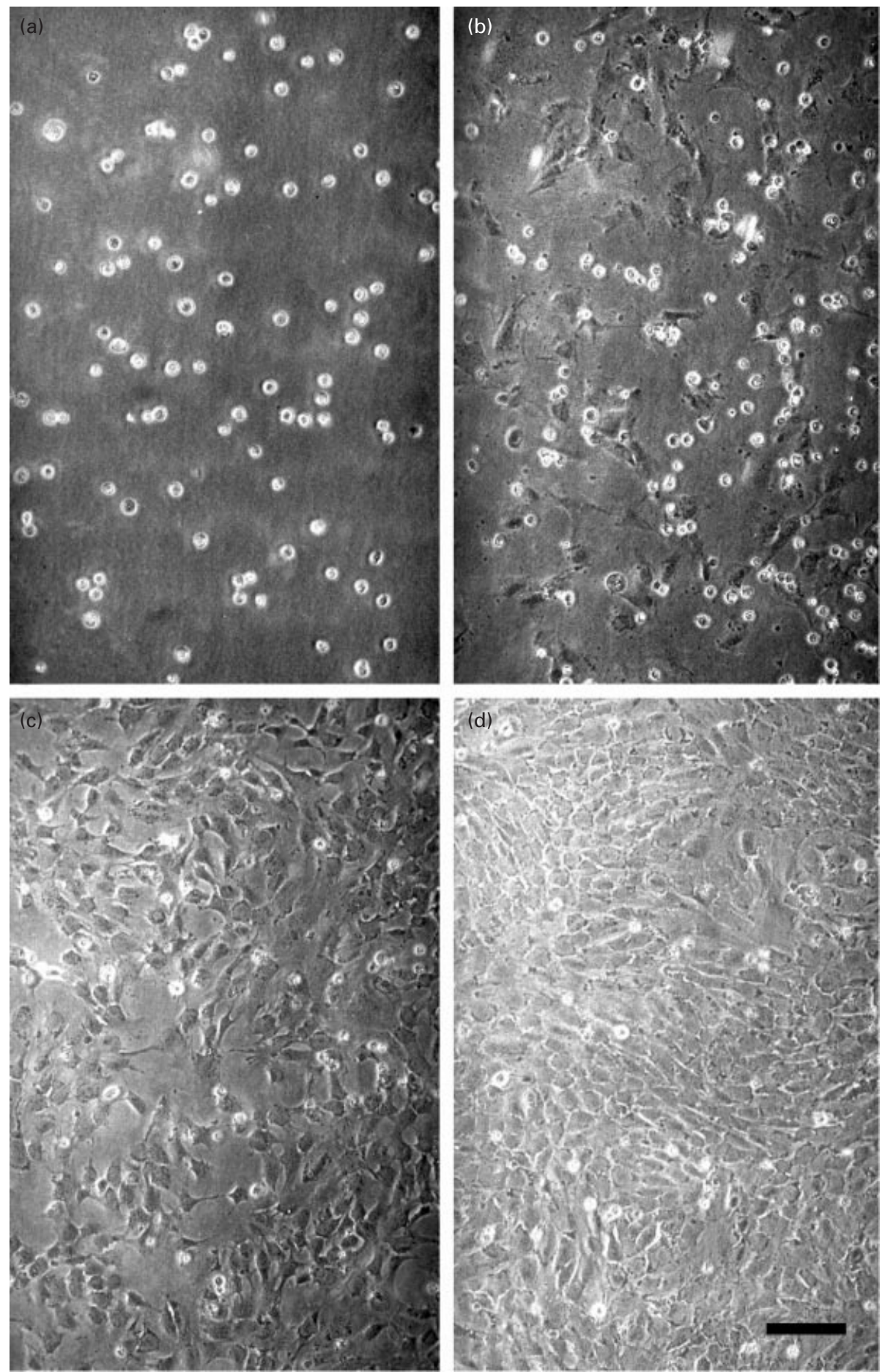

Fig. 3. Bovine cells seeded after 15 days of refrigeration. (a) Cells were seeded at a density of $5 \times 10^{4} \mathrm{ml}^{-1}$; (b) cells attached before $24 \mathrm{~h}$ after seeding; (c) cells reached $70 \%$ confluency at $48 \mathrm{~h}$ after seeding; and (d) cells reached complete confluency at $72 \mathrm{~h}$ after seeding. Scale bar represents $100 \mu \mathrm{m}$.

mammal, Dolly the sheep (Wilmut et al., 1997). In the second protocol, cells are cultured in medium with a normal concentration of serum (not induced into G0 stage) and are detached for nuclear transfer when cells reach
70-80\% confluency (Cibelli et al., 1998). Wakayama et al. (1998a) developed the third protocol in mice: donor cells are collected from fresh tissue and the donor nucleus is injected directly into the cytoplasm of enucleated oocytes. 
In the present study, cultured cells were stored at $4^{\circ} \mathrm{C}$ for 1 or 2 weeks and used as donor cells in nuclear transfer. Non-refrigerated donor cells subjected to the same procedure and parameters served as the control group. There were no significant differences in development in vitro and early development in vivo between embryos constructed with refrigerated cells and those constructed with non-refrigerated cells. The density of viable cells after day 1 of refrigeration decreased to about 30\%; however, the rate of decrease tended to slow down with increasing duration of refrigeration. When a starting density of $2 \times 10^{5}$ cells $\mathrm{ml}^{-1}$ was used, after 15 days of refrigeration the density had decreased to $1 \times 10^{5} \mathrm{ml}^{-1}$, which was adequate for nuclear transfer. Moreover, the viable cells had sharp edges and homogenous cytoplasm, and were easily distinguished from dead cells under standard microscopy, thus refrigeration did not appear to have a negative effect on the viable cells before micromanipulation.

When cells were seeded at $5 \times 10^{4} \mathrm{ml}^{-1}$ after refrigeration for 15 days, many cells had attached after $24 \mathrm{~h}$ and after $48 \mathrm{~h}$ had reached $70 \%$ confluency. Chromosome analysis shows that most refrigerated cells maintained a normal chromosome number, similar to non-refrigerated cells. This result indicates that refrigeration for 15 days has a minimum effect on chromosome numbers.

The development in vitro and early development in vivo of nuclear transfer embryos derived from refrigerated cells was not significantly different from those of embryos derived from non-refrigerated cells. The stability of the cell nucleus has been observed in other studies on intra-cytoplasmic sperm injection (ICSI). For example, spermatozoa maintained in a harsh environment (such as freeze-dried or frozen without protectant) and then injected into the cytoplasm of an oocyte, resulted in normal fertilization and normal offspring (Wakayama and Yanagimachi, 1998; Wakayama et al., 1998b). These studies indicate that the activity of the cell is not synchronized with the activity of cell nucleus, that is, 'dead' spermatozoa maintained in a poor environment may have nuclear material capable of supporting full-term development.

In addition to refrigeration, cells can also be stored using cryoprotectants (Wells et al., 1998, 1999). However, the potentially harmful effect of cryoprotectants can be avoided by using the refrigeration method, which does not require a cryoprotectant and is effective for short-term storage.

Nuclear transfer involves the reprogramming of the donor nucleus in ooplasm and it is still not known whether refrigeration has any effect on reprogramming. Improvements in the refrigeration protocol used in the present study could be made, as the density of viable cells decreases rapidly during day 1 of refrigeration. Cells refrigerated for a longer duration were not used as donor cells in this study because of time limitations. However, it is possible to culture donor cells successfully after 120 days of refrigeration (J-L. Liu and D-Y. Chen, unpublished). Investigating the effects of long-term refrigeration on nuclear transfer may provide new information that is useful in cloning research and the cloning industry.
The authors wish to thank M. Luo, Y. Tao, Y-T. Li, Y. Liu and Y. Li at the Anhui Agricultural University, and K-Z. Yin, S-Y. Zou, J-B. Luo, C-S. Lu and X-B. Huang at the Hefei Dairy Company for their kind assistance. The authors extend their thanks to J. Riesen at the University of Connecticut for his critical reading of this manuscript and to B. Enright for kindly assisting with figure design. This work was supported by China National Natural Science Fund (No. 39830280).

\section{References}

Baguisi A, Behboodi E, Melican DT et al. (1999) Production of goats by somatic cell nuclear transfer Nature Biotechnology 17 456-461

Boquest AC, Day B and Prather RS (1999) Flow cytometric cell cycle analysis of cultured porcine fetal fibroblast cells Biology of Reproduction 60 1013-1019

Campbell KH, McWhir J, Ritchie WA and Wilmut I (1996) Sheep cloned by nuclear transfer from a cultured cell line Nature 380 64-66

Cibelli JB, Stice SL, Golueke PJ, Kane JJ, Jerry J, Blackwell C, Ponce de Leon FA and Robl JM (1998) Cloned transgenic calves produced from nonquiescent fetal fibroblasts Science 280 1256-1258

Denning C, Burl S, Ainslie A et al. (2001) Deletion of the alpha(1,3)galactosyl transferase (GGTA1) gene and the prion protein (PrP) gene in sheep Nature Biotechnology 19 559-562

DiBerardino MA (1997) Nuclear potential of mammalian cells. In Genomic Potential of Differentiated Cells pp 180-213 Ed. MA DiBerardino. Columbia University Press, New York

Freshney RI (1994) Disaggregation of the tissue and primary culture. In Culture of Animal Cells 3rd Edn pp 127-147 Ed. RI Freshney. Wiley-Liss, Inc., New York

Kato Y, Tani T, Sotomaru Y, Kurokawa K, Kato J, Doguchi H, Yasue H and Tsunoda Y (1998) Eight calves cloned from somatic cells of a single adult Science 282 2095-2098

Kubota C, Yamakuchi H, Todoroki J, Mizoshita K, Tabara N, Barber M and Yang X (2000) Six cloned calves produced from adult fibroblast cells after long-term culture Proceedings National Academy of Sciences of the USA 97 990-995

Liu JL, Wang MK, Sun QY, Xu Z and Chen DY (2000) Effect of telophase enucleation on bovine somatic nuclear transfer Theriogenology $\mathbf{5 4}$ 989-998

McCreath KJ, Howcroft J, Campbell KH, Colman A, Schnieke AE and Kind AJ (2000) Production of gene-targeted sheep by nuclear transfer from cultured somatic cells 405 1066-1069

Onishi A, Iwamoto M, Akita T, Mikawa S, Takeda K, Awata T, Hanada H and Perry AC (2000) Pig cloning by microinjection of fetal fibroblast nuclei Science 289 1188-1190

Rosenkrans CF and First NL (1991) Culture of bovine zygote to the blastocyst stage: effect of amino acids and vitamins Theriogenology 35 266 (Abstract)

Wakayama T and Yanagimachi R (1998) Development of normal mice from oocytes injected with freeze-dried spermatozoa Nature Biotechnology 16 639-641

Wakayama T, Perry AC, Zuccotti M, Johnson KR and Yanagimachi R (1998a) Full-term development of mice from enucleated oocytes injected with cumulus cell nuclei Nature 394 369-374

Wakayama T, Whittingham DG and Yanagimachi R (1998b) Production of normal offspring from mouse oocytes injected with spermatozoa cryopreserved with or without cryoprotection Journal of Reproduction and Fertility 112 11-17

Wells DN, Misica PM, Tervit HR and Vivanco WH (1998) Adult somatic cell nuclear transfer is used to preserve the last surviving cow of the Enderby Island cattle breed Reproduction Fertility and Development 10 369-378

Wells DN, Misica PM and Tervit HR (1999) Production of cloned calves following nuclear transfer with cultured adult mural granulosa cells Biology of Reproduction 60 996-1005 
Wilmut I (1998) Cloning for medicine Scientific American 279 58-63

Wilmut I, Schnieke AE, McWhir J, Kind AJ and Campbell KH (1997) Viable offspring derived from fetal and adult mammalian cells Nature 385 810-813

Wolf E, Zakhartchenko V and Brem G (1998) Nuclear transfer in mammals: recent developments and future perspectives Journal of Biotechnology 65 99-110
Wolfe BA and Kraemer DC (1992) Methods in bovine nuclear transfer Theriogenology 37 5-15

Received 11 May 2001.

First decision 26 June 2001.

Accepted 27 July 2001. 